\title{
Economic Confidence as a Factor of Management of Russian Banks' Financial Stability under the Condition of Geopolitical Risks
}

\author{
Alina V. Andreeva ${ }^{1}$ \\ ${ }^{1}$ Rostov State Transport University, Rostov-on-Don, Russia \\ Correspondence: Alina V. Andreeva, Rostov State Transport University, Rostov-on-Don, Russia, ap. 34, 73 \\ Sokolova St., 344000, Russia. Tel: 79-28-144-4410. E-mail: alya_andreeva@mail.ru
}

Received: August 1, 2014 Accepted: September 1, 2014 Online Published: November 14, 2014

doi:10.5539/ass.v10n23p102

URL: http://dx.doi.org/10.5539/ass.v10n23p102

\begin{abstract}
The article considers some instruments and technologies which can substantially improve economic confidence at the Russian market of banking services. The article also covers several factors which restrict possibilities of effective management of Russian commercial banks' financial stability in the current conditions. Geopolitical risks realization and their growing influence on development dynamics of the Russian banks call for the necessity of development of new methods and instruments of financial stability management, which is closely connected with increasing of profitability of client operation and creation of system of risk management in banks. The author develops a methodology for calculating the return on customer service, as well as a technique to control profitability of customer service. To facilitate the use of this method the calculation of profitability of customer service to be integrated into a customized version of banking software in the risk management system, so the author creates private banking scheme of strategy in dealing with clients. The author also conducts website expertise in private Banking segment of six major private banks, analyzes marketing management of the bank 'financial strategy on the example of OTP Bank, as well as developed and tested a methodology to assess the maturity level of financial services in a commercial bank, including a major components of management of financial stability.
\end{abstract}

Keywords: economic confidence, financial stability of banks, geopolitical risks, profitability of client operation, Russian banks

\section{Introduction}

Russian banking services market reduces the rate of growth. Imposed by the United States and European Union sanctions will have the greatest impact on energy, defense and finance sectors of the Russian economy, which may significantly slow down economic growth and reduce the stability of the Russian companies. Particularly strong effect sanctions could have on the financial stability of the banks that are denied access to the capital markets, the United States and the European Union. Get out of this situation can only be through the diplomatic channel.

In the context of the implementation of the geopolitical risks in the Russian market of financial and credit services to observe the process of reallocation of resources in favor of large state-owned banks in the capital, compressing the interbank lending market and a sharp decline in assets at the central bank for the refinancing operations. For the first quarter 2014 the geopolitical risks associated with the unfolding crisis in Ukraine has increased significantly. It should be noted that, in the opinion of the President of the ECB, Mario Draghi, these risks have a greater negative impact on the euro area than in other regions of the world, therefore, these factors can slow the growth of the European economy.

Post-crisis recovery of the eurozone economy is not enough going on evenly structural reforms are not characterized by high dynamics and private investments are still at a fairly low level. According to published data of the European Commission, the export of food products, beverages and cigarettes in Russia in 2013 amounted to 12 billion euros. The embargo will contribute decrease of prices for agricultural products and hit many EU producers, primarily from Eastern Europe, for which the Russian market - is the main market - note the experts (Kravchenko, 2014). 


\section{Method}

Poor quality of service of loans is due to the high cost of resources for borrowers and low-credit banking customers. This level of creditworthiness should be identified in the decision to grant a loan. The basis of this control is the formation and development of qualitatively new system of risk management in the Russian commercial banks, which served as an essential attribute of the management of financial stability.

Experts in risk management play a key role in the formation and implementation of the control system of financial stability of the bank, eliminating risks of mistrust between the parties of the market due to the fact that they have more information about the risks, borrowers and management tools of financial stability.

Development of risk management at the bank facilitates the introduction of new technologies in the bank, including information technology and risk management systems of indicators for early detection and prevention of banking risks. Risk management permits better manage liquidity Stu and financial stability. To meet the challenges of the financial stability necessary to use diversified banking risk management system, improve the profitability of the bank and the customer experience.

Quality customer service also contributes to the profitability of the bank on the level of economic confidence in the banking system, and customer loyalty to a particular bank. The total return is the total return on the customer service of a credit institution.

To manage the profitability of customer service bank, first of all, must have information about the actual current level of profitability, and this information should be build on an ongoing basis. To determine the profitability of the bank needs information on the activities of the bank and the appropriate technique.

$$
\begin{gathered}
\text { Profitability }=\frac{\text { Profit }}{\text { Costs }}=\frac{\text { Revenues }- \text { Costs }}{\text { Costs }} \\
\text { Revenue }=\frac{(100-\text { FMR })}{100} \times \mathrm{R}
\end{gathered}
$$

FMR - Rate of deduction into the Fund of Mandatory Reserves

\section{$\mathrm{R}$ - Average daily residues on clients' accounts}

Note that some complexity is calculation of the amount of total expenditures, including the amount of indirect costs. According to experts, the most accurate you can calculate the amount of interest-expenditure on the basis of the average daily debt to asset operations and the cost of attracting. Calculation of the amount of indirect costs that go into the content of the bank's staff, rent, depreciation and other expenses of the bank, usually causes difficulties due to the need to share the distribution of these costs on a particular client (Grishkov, 2014).

Usually offer to distribute indirect costs in proportion to the number of clients or on the basis of their share in various operations. The implementation of such a method of calculating the amount of total expenditures, including the amount of indirect costs, permits, according to experts, to carry out rough, and, hence, to impute an indicator of profitability of customer service.

For an accurate calculation it is necessary to apply the following formula:

$$
\mathrm{Z}=\mathrm{N}_{1} \times \mathrm{Z}_{1}+\mathrm{N}_{2} \times \mathrm{Z}_{2}+\ldots+\mathrm{N}_{\mathrm{i}} \times \mathrm{Z}_{\mathrm{i}}
$$

$\mathrm{Z}$ - indirect costs of customer service,

$\mathrm{N}_{\mathrm{i}}$ - number of operations of one type for a time period,

$Z_{i}-$ cost of a single operation of exact type.

To facilitate the use of this method of calculating the profitability of customer service are be integrated into a customized version of banking software in the system of risk management. Using this tool will provide the bank and get the results of the evaluation experts profitability on an ongoing basis for all customers.

\section{Results}

The Government of the United States is expanding sanctions against Russian commercial banks and defense companies. Office of Foreign Assets Control (OFAC) blocked the export of certain goods and technology that are used in the energy sector of the Russian economy, as well as to suspend the issuance of credits that contribute to the growth of exports to Russia and finance internal projects the country's economic development. 
Department of the Ministry of Finance of the United States responsible for the implementation of the sanctions the United States, closed to-speed on the capital market for Russian state banks, prohibiting economic agents operation to provide these Russian banks debt financing of the new share capital. Limitations are common to conduct transactions and other operations with new shares and debt instruments of these banks.

European Union at the end of July 2014 and significantly extended sanctions against Russia, limiting setoral cooperation and access to public financial institutions in Russia to the EU capital markets.

Retaliatory sanctions of the Russian Federation in the form of a ban on the supply of food and agro sector of the European Union may lead to the formation of excess supply of these products in the European market, and possibly provoke a decrease in the prices of agricultural production. However, the relative decline in food prices, which will benefit the European economy, may complicate the economic situation in the eurozone. The European Central Bank is trying to prevent deflation in the European Union, and the reduction of prices on food markets is contrary to his intentions.

Given that the share of the Russian Federation accounts for less than $10 \%$ of exports Agricultural extension products from the European Union, it is possible to draw a conclusion about the upcoming price increase for these products in the domestic Russian domestic market.

In July 2014 the consumer price index in the euro area rose by $0.4 \%$ compared to the same period in 2013 Experts say that this is the lowest level of this indicator over the past 5 years. Meanwhile, according to the statistics, the target level of inflation, reflecting the policy of the ECB, is slightly less than $2 \%$. Downside risks to growth and inflation in relation to geopolitical risk increases, so, according to analysts, is extremely low inflation in the euro area can be maintained over a long period (Overchenko, 2014).

Note that currently the Finnish company expects profit decline and the emergence of departure because of restrictions imposed by Russia in response to the alleged sanctions. For example, the company Valio Ob has identified that stops all the lines for the production of products for sale in Russia. Geopolitical risks reduce the level of economic confidence, increase the uncertainty of consumers and producing products, as well as commercial banks that provide services to economic agents in these countries.

As a result of the implementation of geopolitical risks and the expansion of the military conflict in Ukraine, the growth of the Eurozone economy may fall and be lower than the forecast of the ECB (1\% in 2014). However, the ECB kept its key interest rate at $0.15 \%$ on deposit products rate was minus $0.1 \%$, and margin loans $-0.4 \%$.

In the face of the deteriorating geopolitical situation and the actual suspension of economic co-operation between Russia and the developed countries to the Russian Federation faced with the task of restructuring the current fiscal, monetary and financial-credit policy. This determines the need for modernization of the development strategy of the Russian commercial banks, aimed at ensuring financial stability. Application sectorial sanctions not only limits the ability to attract the necessary resources for the development of Russian banks, but also reduce in the near future value of their shares and ranking position in the global financial market.

The possibility of tighter introduced in July 2014 economic sanctions against Russia has a high probability of realization. Tougher sanctions involves freezing the assets Patriotic companies located abroad, the introduction of additional restrictions on Russian exports of hydrocarbons. Given the fact that in a few years the United States will be able to build on the European market infrastructure for delivery of shale gas is likely that they will be able to replace Russia's exports to Europe, albeit at higher prices.

Implementation of such a strategy and restrictions for Russian companies the possibility of attracting sensitive technologies adversely affect the resumption of economic growth in Russia, the level of sustainability of the mining companies and state-owned banks, will reduce the level of trust between economic agents, as well as the ability to create an attractive investment climate and business environment developed.

Sanctions in the future also negatively affect the price of the assets of Russian companies and commercial banks, which is inevitable in this case, the reduction of the available segments of the global market and the possibility of a profitable business in the future.

In the case of systemic risks in the negative scenario of economic obligations of Russian banks, most likely to remain unfulfilled. This is due to the fact that these commitments first, denominated in foreign currency, and secondly, the risk of default of these obligations - high, as the assets of commercial banks themselves can be frozen. The consequence of such circumstances is a change in the model of investment behavior of market actors, especially the decline of interest of economic agents in Russian assets, including operations in Russian rubles. 
Russian banking system needs stability. The unstable situation and the imbalances in the financial sector will reduce the financial stability and competitiveness of Russian banks to pro-space of the Eurasian Economic Union, which was established in May 2014 and needs to be preferences for development, rather than economic constraints (Osipov, 2014).

Restricting the activities of credit institutions the new sector sanctions aimed primarily at Russian commercial banks with state participation. Contents taken sanctions aimed at hindering the access of Russian banks in the financial market of the European Union. According to experts, this list already includes the most financially stable banks: VTB Bank and banks that belong to the group VTB (VTB 24 Bank of Moscow, "VTB Capital", "VTB Leasing", "Hals Development"), as well as Agricultural Bank (Lavrov, 2014).

In order to limit Russia's access to the capital markets of the EU, nationals and companies of the Euro-Union exhibited a ban on the purchase and sale of new bonds, stocks and other financial instruments with a maturity of more than 90 days issued by banks with state participation in the capital of the bank-E development and their subsidiaries (Lykova, 2014).

Limiting factors act as the conditions under which European companies will not be able to provide services to Russian banks for placement of financial instruments. In a statement, the European Union restrictions on long-term loans to Russian banks with state teaching, as well as bonds and stocks. If the EU sanctions copy American, then for more than 90 days, so the same will be banned.

At the same time, extend the sanctions list and the United States. The list of companies that American lenders cannot provide funding in any form for a period exceeding 90 days, marked VTB, Bank of Moscow, the Agricultural Bank, Gazprombank and VEB.

In connection with the establishment of restrictive sanctions majority of Russian banks are faced with the problem of providing liquidity and is now concerned about the search for new sources of funds. One of the tools that can ensure the financial sustainability of private banks is Xia securitization. This tool is in the Russian market only being tested. Securitization is sufficiently effective mechanism to attract long-term funding and reduce the burden on capital, which can work not only in the period of growth, but also in a recession and economic stag-nation.

Opportunity for effective use of this tool is linked to how the mechanism of se-securitization will be limited to regulatory standards of the Bank of Russia. Mega-regulator of the Russian financial market has not made a final decision on the parameters and conditions of use of the instrument. Corridor application securitization can limit market development banking services, or create incentives for the growth of credit activity of Russian banks.

The post-crisis strategy for development of the Russian financial and credit market needs to reformulate-matting to ensure financial stability of commercial banks. Financially stable bank is directly related to the restriction of risks in banking, primarily credit and operational risks, the presence of "problem" loans, as well as increased external risks affecting the operations of the bank.

External risks are low quality of the business environment, liquidity problems and non-competitive market conditions. In this regard, the creation of conditions for fair competition in the Russian-bank market of banking services to create a more effective system of financial stability of the bank.

Management of financial stability of commercial banks is based on an effective risk management system, which allows adequately assess the assets and increase the profitability of the banking business. The problem of low profitability of the banking business is related in many ways to the presence of problematic loans, the share of which was the re-grow due to the growth of credit activity of banks, implementing a strategy of aggressive marketing. Note that the increase in the proportion of "problem" loans, which do not generate incoming cash flow, not only reduces the financial stability of the bank, but also its credibility with investors and counterparties.

Between the Bank of Russia as a market regulator and the professional community-length enough periods of time shall be consulted on the management problems of financial stability and for reducing the requirements, including the outcomes of the Basel III.

It should be noted that the consolidated opinion of the professional community in Europe allows us to reduce the pouring-requirements regarding liquidity ratios, and today the list of included or to be included securities backed by mortgage loans, as well as the tools provided and non-mortgage loans.

Under pressure from the professional community have been reduced capital requirements for securitization transactions within the requirements of the Basel Committee and the agreement (Basel). Developing mechanisms to encourage the development of industrial production, the ECB announced a promising possibility of 
implementing the program of redemption of securities backed by the assets in order to maintain economic activity agents.

The Russian financial market active economic agents are much less than in developed markets. You can select no more than 25-30 participants of the market, which have the capacity to pro-conducting these transactions. Due to the fact that banks have sufficient portfolios for securitization, there is little that the profitability of securitization transactions may be low, as the size of the transaction; paradise could be cost-effective, valued not less than 3 billion rubles. The increase in transaction, volume increases and its cost-effectiveness, reduce the organizational and economic costs of the bank on the development and implementation of securitization.

It should also be noted that regional and medium-sized Russian banks could face a factor in reducing the economic confidence of customers. This is primarily explained by preserving sculpt the market nervous situation, initially caused by the regulator review the licenses of considerable amounts of several banks, including some medium-sized banks. Due to this negative sentiment of economic agents in the local market further fueled by the pressure on the exchange rate because of the events in the Ukraine. Increase the key rate by the Board of Directors of the Bank of the Central Bank, these from 7.5 to 8\% per annum 25 July 2014 led to a rise in the cost of borrowing in the interbank market and the bond market.

This is due to the regulator's decision slowdown in consumer price growth in the inflation risks associated with geopolitical tensions which have an impact on the dynamics of the national currency, as well as changes in tax and tariff policy.

Strengthening these risks will lead to the preservation of inflation expectations at a higher level and create a high enough threat of exceeding the target level of inflation in the coming years. PRIN-th solution is aimed at slowing the growth of consumer prices to the target level of $4.0 \%$ in the Medium-term. In case of continued inflationary risks at a high level, the Bank of Russia will continue to increase the key rate.

In the post-crisis the Russian economy the determining factor in the creation of a favorable investment climate in modern conditions becomes economic confidence among market agents. Consider the categorical sense of the term. Trust is a process that is used to transfer and exchange of knowledge. According to scientists, "confidence is a confidence in the future behavior within the network of agents' interactions" (Lyasco, 2004).

Usually in the conditions of the emergence of economic imbalances, economic agents are negatively disposed to the authorities and market regulators. To create the institution of trust in the country need to constantly explain to investors and economic agents to make sense of change. In Russia, there are now a large number of institutional problems, so trust agents to the state of the Russian economy and the quality of the business environment is preserved for a long time is not enough to lower level.

In addition, the loss of confidence in Russia at the international level will attract new technology for the development of industrial companies and loans to stimulate consumer demand in the economy and to provide a large external debt refinancing of banks and non-organizations. The imposition of sanctions will not only enhance the observed disparities in the Russian economy, but will also contribute to the reduction of trust between economic agents that adversely affects in business and investment activity of the business. Reduction of economic confidence in the market and business activity of Russian companies will increase the stagnation of the economy and its investment attractiveness-productivity of the.

Even more complicated is the situation between economic agents in the Russian market fi-cial and credit services. Recession in Russia in 2008-2009 almost led to the end of a long cycle of rapid credit expansion in the country. Extensive marketing strategy has led banks higher loan losses and a high level of loan restructuring, reduction of the external debt and active state support of banks and industrial companies. Increased activity of commercial banks resumed in 2011 at a high level when the volume of loans in the Russian banking system increased by $27 \%$.

Currently, the credit risk on the Russian banking market remains high. The amount of arrears on loans also increased. Despite the fact that than $50 \%$ of the restructured bank loans are currently performing loans, according to experts, the Russian banks may take several years to write off bad loans from the balance sheet.

From 2012, Russian banks have resumed an aggressive policy of credit expansion based on new marketing strategies and actively lend to businesses and households is to dilute the share already issued the "problem" loans granted earlier. As a result, there is the increased credit risk of banks and reduce their financial stability. At the moment in the investigation of these risks manifested in a decline in the quality of borrowers and a high level of defaults. 
The greatest difficulty with ensuring financial stability experienced a small Russian banks, which by the end of 2013, faced with a large outflow of capital, experienced the impact of reduce the confidence of depositors. After the revocation of licenses of a number of medium-sized banks investors began transitions dit-on service to large banks with state participation. During this period, the volume of retail depot posits with banks in terms of assets takes places from 51-th to 200 -th, decreased on average by $6.1 \%$, while the 50 largest banks in the volume of retail deposits increased by $9.4 \%$.

In the 10 largest banks in the volume of retail deposits grew by $12.1 \%$. The low trend in larger banks was particularly pronounced in the more affluent customers. They are eager to go on service more reliable banks, as large deposits (in excess of 700 thousand. Rubles) are not fully guaranteed, while deposits in state banks perceived by the population as a riskless.

Between banks increased competition not only for the available cash flow of households, but also for the corporate funds of depositors. At the same time, Russian companies that host significant amounts of deposits, gradually returned to service in the large private banks and banks with Member donative participation, despite the fact that interest rates to attract deposits in these banks is lower than in small and medium-sized banks. This is due to increased risks in the Russian market bank services and a decrease in customer confidence in banks pocketbook.

If we consider the lending activity of Russian corporate borrowers, the most common of credit resources are turning to the bank Russian trading company, primarily retailers. High lending activity at the end of 2013 showed as leasing companies, research institutes, and enterprises of machine-building sector, construction companies, transport and communications.

However, due to the limited liquidity in the Russian banking market and inflation of resources associated with an increase in the key rate of the Central Bank, and increased credit risks.

If the Russian banks will restrain the growth in lending rates, they are, on the one hand, reduce the financial stability and, on the other hand, can cause an increase in demand for credit from the customers who have already begun to feel the difficulty in attracting new loans and the replacement of existing in other banks.

Against the background of an unstable situation, the Russian foreign banks and their customers tend to use credit ruble loans, so now in the credit market lending in foreign currency are reduced. The objectives of management of financial stability, defined on the relevance of improving risk-management commercial banks to implement the weighted-term credit policy.

An additional risk factor for small-size banks is usually high level concentration of their deposit base. Many small and medium-sized banks in the 20 largest depositors accounted for about $50 \%$ of total liabilities. It may be noted that small and medium-sized banks have limited flexibility to increase the inflow of deposits by increasing in interest-rates on deposits, since this increase is closely monitored by the Bank of Russia. Possibility of borrowing in the financial markets also will be under pressure.

Financial sustainability of small-sized banks may decline due to the limited perspective ability to obtain financing on the public debt markets. This is due the introduction of liquidity standard under Basel III, which does not take into account the commitments of the banks, as part of liquid assets and limit situation in which banks bought back bonds of other banks for collateral with the Central Bank.

Thus, due to the emergence of the Russian market of additional risk factors associated with liquidity and a reduction in customer confidence in banks pocketbook, these market operators cannot cope with ensuring financial stability, as well as face-restriction factors of growth due to emerging problems with financing. Limitation percent of the deposit-there reduced competitive ability of small and medium-sized banks in the market to raise capital.

Under these circumstances, small-format Russian banks to a greater extent will create risks associated with possible liquidity crisis arising in the Russian market. Moreover, the pressure on the interbank market has resulted in scaling up the use of the Bank of Russia refinancing mechanisms for addressing the financial sustainability of the Russian banks.

Increasing dependence of banks on the financing provided by the Bank of Russia, change management methods and tools of financial stability. The majority of these funds come in the form of short-term bank repo operations, which are used as collateral mainly low sovereign and corporate bonds. 
Reduction in resources available liquidity and increased dependence on the ability of small-sized banks to attract short-term funding sources can not only reduce their credittiveness, but also the financial stability and even solvency.

In late 2013, the financing of the Bank of Russia, the volume of which reached at the end of 20134.1 trillion rubles, was $7.8 \%$ of total liabilities and equity of banks (Popkova \& Tinyakova, 2013). However, a possible decline in the funding and liquidity may adversely affect the financial stability of the medium and small banks (see Fig. 1).

Billion, RUB

$\%$, Assets

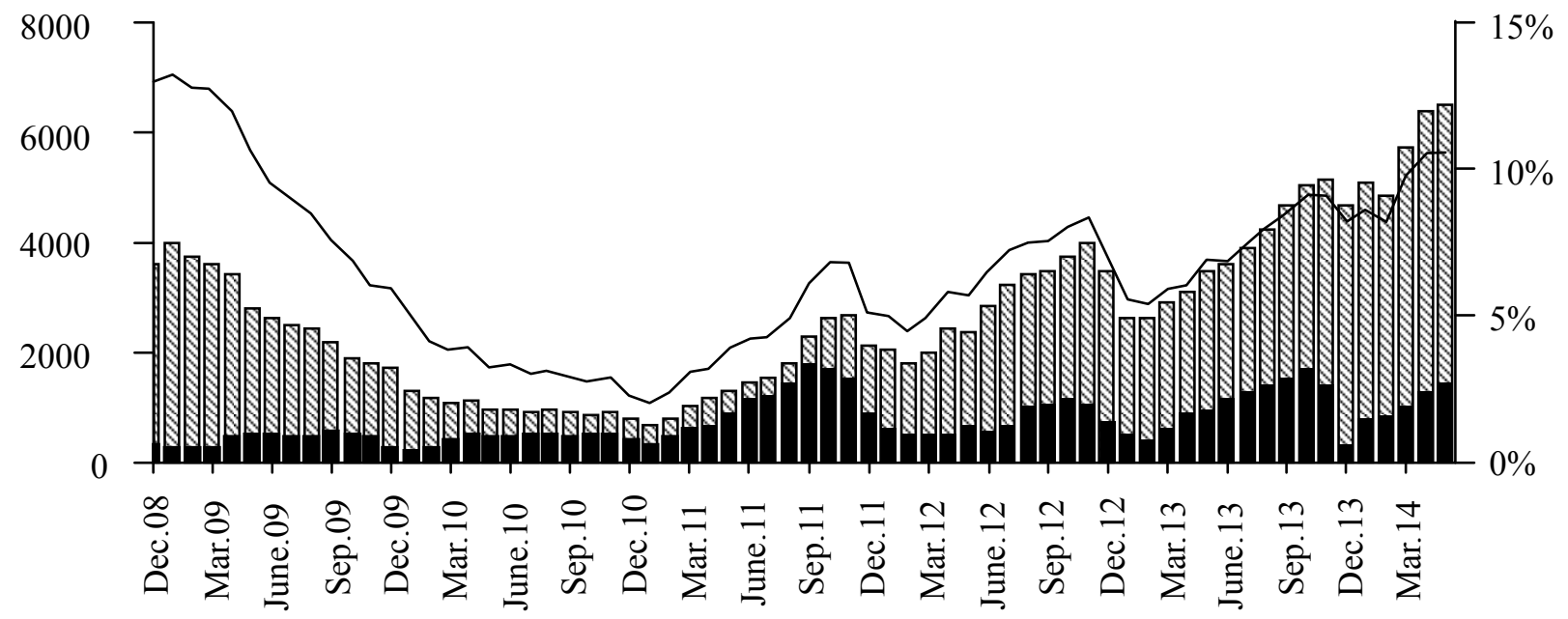

पIInstry of Finance Deposits in banks

Banks debt to the Central Bank of the Russian Federation State funding, $\%$ assets (on the right scale)

Figure 1. Total state funding of Russian banks, billion rubles and \% of assets (Kuvshinov, 2014)

In determining the strategy of working with clients, marketers find it necessary to use a matrix of customer profitability, proposed by British experts Martin Christopher and Helen Peck, adapted to the banking activity (figure 2).

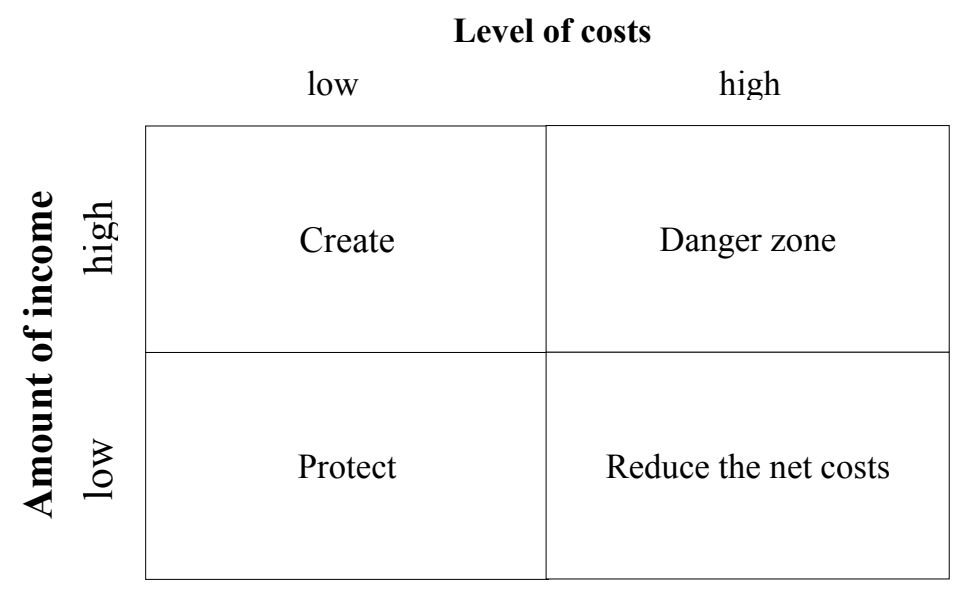

Figure 2. Private banking scheme of strategy in dealing with clients

Customers with a high income and low cost are at "Protect" and should be considered Xia VIP-clients. The strategy of working with them is to build such relationships with they will not look for an alternative bank. 
Customers with a high income and high costs are located in the zone "to reduce the cost". For the choice of strategy is necessary to conduct a thorough analysis of the cost structure and to develop measures to reduce them.

Managing customer profitability is based on the calculation of profitability, which should pro-plagued complex and on an ongoing basis. Customers with low income and low cost, as the great-rule, it is very young people or senior citizens are at risk, "Create". These clients are the largest segment of the Russian market, therefore, requires a comprehensive approach to the implementation of the marketing strategy of the bank, aimed at ensuring confidence in the bank, customer loyalty on a-bank basis to develop an attractive product. Especially they are interested in working with this client group, if they can attract banking products using collateral instruments.

For the preparation of such specialized products that are of interest to consumers and make confidence in the bank, you need to monitor the effective demand of the customer segment of the market for banking products and services. Attracting clients such interesting bank if they have a professional education and permanent employment, which can advance to higher income?

Customers with low incomes and high costs are in the "Danger Zone". This is the problem of customers, their service is a loss for the bank. Likely from such clients, the bank must get rid of. To implement the objectives of the financial stability of the construction of the marketing strategy of interaction with the customers of the bank should be based on the formation of a trusting relationship with the profitability of their monitoring service.

Thus, in the face of increasing economic imbalances in the Russian banking market as a result of the implementation of the geopolitical risks, and increase the factors negatively affecting the maintenance of financial stability of a commercial bank, an important area of risk management system performs the task of building a cost-effective customer service. Therefore, the main source of increasing the quality of management of the bank's assets and the profitability of its work is the increase of profitability of customer service.

At present, Russian small-format banks to attract customers have formed vat systematic approach to credit, to managing various banking risks to create chit-financial stability. The task of increasing the profitability of customer service involves not only the availability of cheap liquidity, but also new technologies of information and network services, as well as professionals with a fairly high level of competence, regardless of the current situation of foreign trade. On the quality of professionals directly determines the level of customer confidence in financial institutions.

For the preparation of such specialized products that are of interest to consumers and make confidence in the bank should be monitored in effective demand of customers in this segment of the market for banking products and services. Attracting clients such interesting bank if they have a professional education and permanent employment, which can advance to higher income?

Customers with low incomes and high costs are in the "Danger Zone". This is the problem customers who create risks and strengthen the financial imbalance of bank assets. On-servicing these customers bring the bank losses and reputational risks.

To implement the objectives of the financial stability of the construction of the marketing strategy of interaction with the customers of the bank should be based on the formation of a trusting relationship with the monitoring of the profitability of their financial and information services.

Effective management of customer service should be specialized and build on the new technologies and targeted information and marketing communications. Access communication channel performs commercial bank that provides a pre-representation not only of banking products and services, but also on the degree of trust between the bank and its clients.

Economic confidence in the most crucial in the provision of services of Private Banking (Private Banking), which relate to technology integrated services (credit, financial, escrow, consulting, etc.) The most affluent customers prefer (segment VIP) large private banks and banks with state participation.

On today's competitive market, only a high degree of confidence in the bank can be acted, drinking motivation for consent to transition to this form of service. Revision of the Russian banking magazine "Banking Review" has assessed the Bank's website in order to test the control system the customer service segment of the VIP. Reference Group has provided from sites viewed segment of private banking most professional website PSB, which was approved by the majority-tion experts in style, and for the information content, and for clarity. In second place was the site of "URALSIB Private Bank". Site a year ago, was rebranded to become more adapted 
to receive information about products and services. Third and fourth positions with the same result in three points shared banks Unicredit and "Ak Bars", which have comparable sites below for User The-heater (Table 1).

Table 1. Website expertise in Private Banking ${ }^{1}$ segment of six major private banks (Katz, 2014)

\begin{tabular}{cccccc}
\hline Place & Points & Bank & $\begin{array}{c}\text { Positive } \\
\text { mark }\end{array}$ & $\begin{array}{c}\text { Negative } \\
\text { mark }\end{array}$ & $\begin{array}{c}\text { Neutral } \\
\text { mark }\end{array}$ \\
\hline 1 & 12 & PSB & 4 & - & - \\
2 & 8 & Bank Uralsib & 2 & - & 2 \\
$3-4$ & 3 & UniCredit & - & 1 & 3 \\
$3-4$ & 3 & Ak Bars Bank & 1 & 3 & - \\
$4-5$ & 2 & LockoBank & - & 2 & 2 \\
$4-5$ & 2 & Bank of Moscow & - & 2 & 2 \\
\hline
\end{tabular}

${ }^{1}$ Notation: 'Positive mark'- 3 points, 'Neutral mark' - 1 point, 'Negative mark' - 0 points.

Sites of banks "Ak Bars", "UniCredit", "Loco-Bank" and Bank of Moscow poorly focused on the sale, so do not differ in the effective management of customer service, so in need of modernization.

\section{Discussion}

Thus, in the face of increasing economic imbalances in the Russian banking market and increase the factors negatively affecting the maintenance of financial stability commercial banks, an important area of risk management system performs the task of building profitable customization. The main source of increasing the quality of management of the bank's assets and of profitability is to enhance the profitability of customer service (Andreevaa, 2013).

Currently, small-format banks to attract customers should form the systems approach to credit, to managing a variety of banking risks, to provide financial-stability-hand. The task of increasing the profitability of customer service involves not only the availability of cheap liquidity, but also new technologies of information and network services, as well as professionals with a fairly high level of competence. The quality of the work of specialists depends on customer confidence in financial institutions.

Significant role in the economic trust between commercial bank and its counter-agents is the quality of the financial activities of the bank, especially the effectiveness of its financial functions. This means that the bank must act in the market as a professional business partners will, on which you can rely in the conduct of business as well as in the development and implementation of financial and credit policies of the company. An example of such a bank in the Russian market is OTP Bank, financial and consulting services which were modernized.

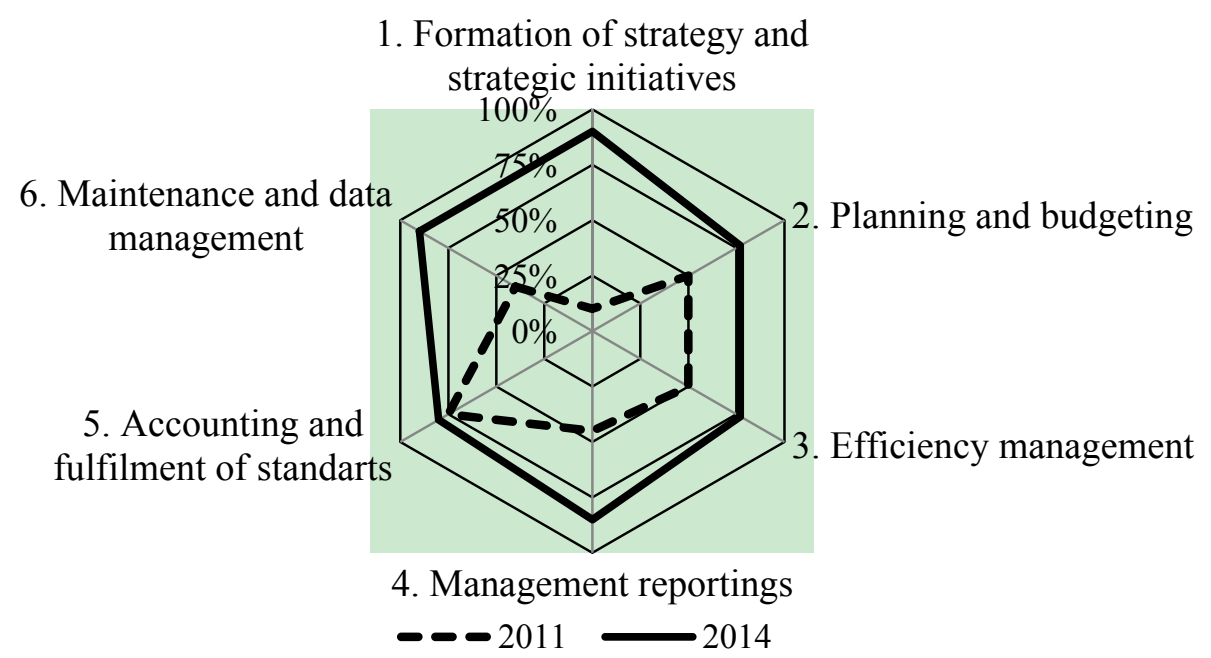

Figure 3. Marketing management of the bank' financial strategy (on the example of OTP Bank) (Smirnov, 2014) 
Important part of the financial services of the bank now act in B-tem risk management and risk controlling, which allowed, according to experts, to significantly improve the maturity of the financial service of OTP Bank (figure 3).

In OTP Bank has established a new structure: Management Strategy and Economic Research, which carries out a number of important functions related to the analysis, forecasting and strategic planning-sky model of economic behavior of the bank's customer interaction. Experience with building such a service, has high practical importance, since it allows to control the financial stability of the bank and to assess the quality of financial decisions.

The Bank's experts developed and tested a methodology to assess the maturity level of financial service in a commercial bank, which includes the basic components of management of financial stability:

- Development and implementation of the financial strategy of the bank;

- formation of strategic initiatives in the selection of tools for the development of market priority niches and market segments;

- $\quad$ planning and budgeting;

- $\quad$ performance management;

- management reporting;

- accounting and implementation of standards;

- $\quad$ service and data management;

- refresher training of financial and accounting services;

- marketing management of financial assets of the bank.

\section{Conclusion}

Thus, if we consider the economic confidence as a factor in the control of financial stability, it can be concluded that for the system cost-effective client service is important not the setting of financial stability, but how it is achieved. You can ensure financial stability of the bank, but he does not wake profitable organization, or, for example, will not be attractive to corporate organization or VIP-clients, if the financial strategy of the bank does not provide the necessary advice, aimed at interaction with the client.

A promising direction in the development of modern commercial bank is a combination of marketing and financial development strategy, aimed at increasing promising market segments and attracting new customers. In the context of the implementation of geopolitical risks Russian banks, its access to capital markets, the United States and Europe, may face problems refinancing its debt-to her and reduced profitability of business, so it is particularly important issue acted as risk management, and increase the profitability of customer transactions.

\section{References}

Andreeva, A. V. (2013). Marketing management of commercial bank competitiveness: Building competence model. Terra Economicus (Space Economy), 11(3), 12-15.

Annual Report. (2013). Central Bank of the Russian Federation. Retrieved from http://www.cbr.ru/publ/God/ ar_2013.pdf.

Grishkov, K. (2014). Managing customer profitability. Bank Review. Best Practice, 2(10). Retrieved from http://bosfera.ru/bo/upravlenie-rentabelnostyu-obsluzhivaniya-klientov.

Katz, E. (2014). Fair Private. Banking Review. Retrieved August 8, 2014, from http://bosfera.ru/bo/taksebe-private

Kravchenko, E. (2014). Threat of Russian. Sheets. Retrieved August 8, 2014, from http://www.vedomosti.ru/ finance/news/31899241/ugroza-iz-rossii\#ixzz39tdnuQcc.

Kuvshinov, O. (2014). Sanctions against Russia increase the risk of political instability. Official site of the newspaper "Vedomosti". Retrieved from http://www.vedomosti.ru/finance/news/29674381/sankciitormozyat-rossiyu\#ixzz39ioJSfg2.

Lavrov, I. (2014). EU and the United States announced new sanctions against Russian banks. Banking Review. Retrieved July 30, 2014, from http://bosfera.ru/press-release/es-i-ssha-novye-sankcii\#sthash.2isekzW W.dpuf.

Lyasco, A. K. (2004). The problem of confidence in the socio-economic theory. Moscow. 
Lykova, N. M. (2014). Building a system of management of problem loans to corporate borrowers. Bank lending, 2(1), 18-22.

Osipov, Y. M. (2014). Eurasian (post-Soviet) international integration as a vital urgency. Philosophy of Economy, l(91), 12.

Overchenko, M. (2014). Russian ban on imports of food will reduce the price for it in the world. Vedomosti.ru. Retrieved August 7, 2014, from http://www.vedomosti.ru/finance/news/31855621/zapret-na-vvozproduktov-pitaniya-v-rossiyu-posposobstvuet\#ixzz39tnj62et.

Popkova, E. G., \& Tinyakova, V. I. (2013). Drivers and Contradictions of Formation of New Quality of Economic Growth. Middle-East Journal of Scientific Research, 15(11), 1635-1640.

Russian and foreign corporates step up efforts to safeguard cash holdings from sanctions. Retrieved from http://www.euromoney.com/Article/3369607/ChannelPage/8959/AssetCategory/9544/Russian-and-foreigncorporates-step-up-efforts-to-safeguard-cash-holdings-from-sanctions.html?copyrightInfo=true.

Smirnov, A. Raising the level of maturity of the finance function of a commercial bank. Official website of the magazine "Banking Review". Retrieved from http://bosfera.ru/bo/povyshenie-urovnya-zrelosti-finansovoyfunkcii \# sthash.FuYoN7cL.dpuf.

\section{Copyrights}

Copyright for this article is retained by the author(s), with first publication rights granted to the journal.

This is an open-access article distributed under the terms and conditions of the Creative Commons Attribution license (http://creativecommons.org/licenses/by/3.0/). 